Biorheology 30, 303-304, 1993

$0006-355 \mathrm{X} / 93 \$ 6.00+.00$ Printed in the USA.

Copyright $\odot 1993$ Pergamon Press Ltd. All rights reserved.

\title{
CONTENTS OF CLINICAL HEMORHEOLOGY, VOLUME 13, NUMBER 2
}

VOLUME 13, NUMBER 2

MARCH-APRIL 1993

\section{CONTENTS}

\section{Conference Communications}

Proceedings of the Eighth International Congress of Biorheology, Yokohama, Japan, 3.8 August $1992-$ Part II

Symposium: The Effects of Diabetes on the Flow Properties of Blood and the Behovior of its Formed Elements

D.E. McMillan

Hemorheological studies in the diabetes control \& complications trial

Non-Conference Communications

Review Article

Platelet activating factor and ischemia

Papers

177 Circadian variation of platelet aggregation and blood rheology

G.L. Messa, C. Frigerio, M. Saletti,

C. Galigani, F. Guideri, M. Franchi,

P. Blardi, F. Laghi Pasini and T. Di Perri

J.F. Brun, C. Fons, I. Supparo, C. Mallard and A. Orsetti

J.F. Brun, C. Fons, I. Supparo, C. Mallard and $A$. Orsetti

J.F. Brun, P. Boulot, C. Fons, F. Frosi, F. Deschamps, B. Bachelard, I. Supparo, J.L. Viala and A. Orsetti

G. Caimi, A. Serra, R. Lo Presti, G. Grifo, A. Romano, A. Catania, G. Francavilla, S. D'Asaro, M. Montana and A. Samo
187 Could exercise-induced increase in blood viscosity at high shear rate be entirely explained by hematocrit and plasma viscosity changes?

201 Relationships between metabolic and hemorheologic modifications associated with overweight

215 Study of some physiological aspects of blood rheology in fetuses by intrauterine umbilical cord venepunctures. Relationships with hemodynamic measurements

227 Red cell Ca2+ content (total and cytosolic) and erythrocyte membrane fluidity in several clinical conditions

(Contents Continued) 
(Continuation of Contents)

S.U. Persson, P. Hedner, L. Cantera and $\mathrm{H}$. Larsson

F. Nobili, G. Rodriguez, S. Marenco, M. Gambaro, B.M. Stubinski and G. Rosadini

N. Tanahashi, Y. Fukuuchi, M. Tomita, S. Matsuoka and H. Takeda

D.R. Rapin, M.S. Islam, M. Vicariot, B. Bourbigot and F.C. Colin
237 Effects of corticosteroids on erythrocyte filterability and blood viscosity in vitro

245 Fibrinogen and cerebral blood flow: A correlative study

253 Erythrocyte aggregability in patients with cerebral infarction with special reference to diabetes mellius

261 Study of hemorheological parameters in patients with postrenal transplant erythrocytosis

269 Abstracts: The 2:nd Scandinavian Symposium on Clinical Haemorheology, Uppsala, Sweden, 4 and 5 April, 1992

\section{Book Review}

S. Witte

277 FIBRINOGEN 4, CURRENT BASIS AND CLINICAL ASPECTS. Editors M. Matsuda, S. Iwanaga, A. Takada and A. Henschen 